\title{
Where is the common ground? Interaction and transfer between European and Russian philosophical culture
}

\author{
Evert van der Zweerde
}

Published online: 5 October 2010

(C) The Author(s) 2010. This article is published with open access at Springerlink.com

\begin{abstract}
In this paper, I discuss and analyze three instances of exchange and interaction between Russian (incl. Soviet) and (West) European philosophical culture: the correspondence between Merab Mamardašvili and Louis Althusser, Jacques Derrida's visit to Moscow in 1990, and a joint Russian-German publication by Nikolaj Plotnikov and Alexander Haardt. The focus is on the implicit mutual perception of philosophical cultures and on the 'micro-politics' of discourse that is at stake in their interaction. Also, it is shown how different contexts-labelled 'philosophical culture', though not in any deterministic sense-are at work in the mutual perception between individual thinkers. Even if philosophical thinking tends to transcend the parameters of 'glocal' situations, this involves a job that needs to be done, individually and collectively, by the philosophers involved. Consequently, this dimension has to be taken into account when analysing such instances of encounter.
\end{abstract}

Keywords Translation · Philosophical culture - Glocalization ·

Intercultural encounter · Asymmetry · Micro-politics of discourse

Eine genuin russische Philosophie ist als Projekt durchaus im Entstehen...

Ulrich Schmid (2003), p. 22

To transcend the limits of one's native culture does not constitute betrayal, because the limits of any culture are too narrow for the full range of human potentials.

Mikhail Ėpstein (1999), p. 82

E. van der Zweerde $(\bowtie)$

Radboud University, Nijmegen, Netherlands

e-mail: evdzweerde@phil.ru.nl 
I'm back in the U.S.S.R.

You don't know how lucky you are boy

Back in the U.S.S.R.

John Lennon, Paul McCartney (1968) ${ }^{1}$

\section{Introduction}

The world in which we live is, among others, marked by a complex process that usually goes under the name of 'globalization', and that has been the topic of a host of academic and non-academic publications. This notion has given rise to many different definitions and periodizations, which need not concern us here: much depends on whether one looks at globalization as a social scientist, a historian, an economist, a member of Bauman's extra-territorial elite (Bauman 1988, 18-26), or a concerned citizen. According to some, the world has been 'globalizing' ever since humankind came into being and networks of commercial and cultural exchange developed-from this perspective, present-day globalization is merely an acceleration of processes that were already taking place, and the difference is quantitative only. According to others, these same processes have reached a qualitatively new level, viz. a level at which the world has become 'one' in ways in which it was not 'one' before and, perhaps more significantly, beyond which further unification seems impossible: the density of networks and connections can still increase, but not their global scope. I start this paper with an admittedly speculative sketch of the present condition of 'our world'.

Most striking, if one takes a little distance, is the fact that those processes that can be placed under the umbrella notion 'globalization', i.e. the 'shrinking' of time and space and the increase in the possible scope of effect of human actions, exist alongside with processes of 'localization' that go in the opposite direction: individuals, groups, discourse communities, etc.-retreating to fixed identities, sticking together, and establishing relations of mutual exclusion without precedent in history. The discursive construction of a plurality of 'worlds' is not the privilege of theorists like Samuel Huntington, but takes place within those worlds, too- the 'Islamic world' being a clear case in point-, and also manifests itself in softer forms such as the multiculturalism that used to be politically correct in Western societies. What these discourses have in common is their 'culturism', i.e. an understanding of culture as a relatively coherent and substantial unit in which some people live and work while others do not (Schinkel 2007). Relations between cultures thus understood take the shape of domination, exclusion, resistance or, at best, toleration.

Bringing the two lines together, the world in which we live can indeed be qualified as being simultaneously one and many in a new way. Since the world, at least in the geographical sense, has always been 'one', and since humankind has always, in a variety of ways (language and religion, for example), been 'many', it must be the 'new way' that makes the difference. The best way to describe this new way is, to my mind, the following: the world-as-a-whole has become the inevitable shared object of action and reflection of humans, yet there is not a single place or

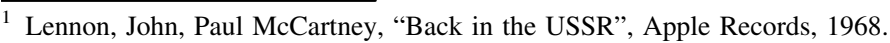


position from which this world-as-a-whole can be approached or assessed, let alone judged. Many forms of subjectivity, here understood as particular combinations of awareness and agency, know themselves to be related to the world-as-a-whole, while at the same time they know themselves to be embedded in specific cultural contexts and backgrounds. What is new is not this constellation in itself, i.e. as a constellation of individual and collective subjects, but the fact that it has become the known shared condition of all. What is new is not the socio-economic and cultural process of globalization, but the inescapable realization (in the double sense) of the world-as-a-whole-a condition aptly described as mondialisation by Jacques Derrida $(2001,13)$.

With very few exceptions, everybody in the world today knows that she or he or the 'we' of which she or he considers herself or himself a member, is one among many similar 'we's', and that the totality of these 'we's' exhausts humankind. This is not the place to engage in a phenomenology of all actual and possible 'we's': many of them exist over longer periods of time, they overlap, they are organized around past, present, and future perspectives, and they may or may not explicitly relate to the world-as-a-whole or to humankind as such. Some are oriented towards an all-inclusive 'we', others are part of 'we' versus 'them' constellations. Everybody in the world also knows that one's actions have effects upon the same world-as-a-whole that are beyond one's control by default. This new human condition serves to explain the proliferation of identity discourses: if the rest of the world is both beyond our control and at our doorstep, the 'we' of each doorstep must define itself in terms that can withstand any confrontation. The basic mode of 'we'-existence worldwide thus has become defensive.

Philosophy has traditionally been an activity in which all forms of determination, whether religious, cultural, or socio-political, are transcended, and at the same time articulated. Philosophy, as Hegel wrote, is its time grasped in thought ["ihre Zeit, in Gedanken erfaßt'], i.e. it is the reflection of a 'time' upon itself, in which it realizes both that it is merely $a$ 'time', while at the same it realizes, i.e. both becomes aware and 'makes real', that there is no other time but the sum of all 'times'. This has not changed: philosophy still is the place where 'a time' grasps itself in thought. The objection that philosophy clearly does not succeed in this 'grasping' since, instead of a unitary position or 'system', it yields a plurality of positions and oppositions (which is the shortest way to describe the present state of philosophy), or that philosophy's role has been taken over by social science or by the variety of holistic visions that yield an overall picture, to my mind does not hold. What if, in fact, philosophy, in its present state of plurality without centre, is grasping its time and thus realizing it at the level of thought? We arguably live in a world without synthesis, without ultimate truth or ground, without repères de la certitude (Lefort 1983, 84), without centre, and we know it. Even those who, like the Pope of the Roman Catholic Church, or militant Islamists, continue to think and argue in terms of a 'centre' (be it geographic or other), know that they have to relate to a plurality of other centres. Given this predicament, there are three modes of relating to it: denial, suppression, and full realization. As has always been the case, philosophy's task is to realize this human condition, to face the predicament and think it (this is not to suggest that it is philosophy's exclusive task its privilege). 
This predicament, and philosophy's position in and with respect to it, provides the general background of any attempt to assess concrete instances of doing philosophy. Philosophy always takes place in a concrete historical, socio-political, and cultural situation, to which it relates reflexively, thus generating part of its own conditions of possibility. This does not mean that all philosophers are permanently aware of this - on the contrary: to the extent to which the conditions of existence of philosophy are 'established', they tend to be forgotten, just like living in a stable democratic polity, for example, makes citizens forget the contingent nature of that polity. The encounter between different philosophical cultures, however, increases this awareness and can make participants self-conscious or, in reaction to that, offensive. $^{2}$ The difference between philosophical cultures comes to the fore, at least, at three points: in differences of external conditions, in differences of language, and in different frames of reference-or horizons, if one prefers. Three examples illustrate these points.

First of all, it can be a shock for a Western philosopher to find that a non-Western colleague is not as free to say whatever she or he thinks, just as it can, conversely, be a shock for this non-Western philosopher to encounter free thinking. The effect can be an attempt to change the situation, it can also be a turning-away, but in both cases, the effect is (increased) awareness of the intrinsic link between philosophical thought and political freedom and of the less than obvious reality of that link. Secondly, it can be a surprise, pleasant or unpleasant, that not everything one thinks can be expressed without remainder in another language: some concepts prove to be untranslatable, well-known examples being notions such as sobornost' or Aufhebung or dispositif (Cassin et al. 2004). Such a confrontation can serve as ground to idealize such concepts, claiming that only a particular language is capable of expressing certain essential truths. It can equally serve as a ground to reject those same notions, blaming Russian or German thinkers for generating endless series of abstractions. The same confrontation can, finally, lead to an adoption of those terms in philosophical parlance or jargon. In all cases, however, the net effect will be a rupture of the naively realistic assumption of a one-to-one correspondence between terms and realities - the assumption can be reclaimed of course, but in that case it will be no longer naive. Thirdly, it can come as a surprise to find that colleagues from a different philosophical culture have a different horizon with different landmarks. Compare the status of 'classical German idealism' in Russian philosophical culture with the reputation of Fichte, Hegel, and Schelling in UK or USA, or the status of ibn-Khaldūn or ibn-Rushd/Averroës in Arabic and in European philosophy respectively. ${ }^{3}$ Again, one can relate to such confrontations very differently, but never 'neutrally': the net effect therefore is, again, increased awareness of the non-obvious character of one's own perception. ${ }^{4}$

\footnotetext{
${ }^{2}$ To be sure, this is not to suggest that there is a finite number of clearly demarcated philosophical cultures: some clearly demarcate themselves, others don't. Often, philosophers only realize the specificity of their own philosophical culture through their confrontation with another, undeniably different one.

${ }^{3}$ In a private conversation, the Moroccan philosopher Mohamed Mesbahi argued that the only Islamic philosopher that the West has ever acknowledged is ibn-Rushd, and they misinterpret him.

${ }^{4}$ For a discussion, see Botz-Bornstein and Hengelbrock (2006), and, in that volume, Vadén (2006).
} 
The upshot of this brief discussion is a realization of the 'glocal' character of philosophical culture, ${ }^{5}$ i.e. of the fact that, although local philosophical cultures retain many of their specific characteristics, related to language, philosophical tradition, socio-political circumstances, etc., they are remarkably and increasingly similar in the ways in which they relate to global philosophical culture: the global perspective, which inescapably presents itself, is adapted to local circumstances, but it is precisely in this process of adaptation that similarities come into being that did not exist before. In this paper, I look at the 'glocalization' of philosophy, the latter being understood as a specific type of intellectual activity that takes place in what I label 'philosophical culture'. The specific focus is on the way in which Russian and European philosophical culture interact with each other. Elementary forms of exchange between philosophical cultures are correspondence, interview, and cooperation. In what follows, I therefore discuss three cases of 'transfer and interaction' between Russian and European philosophy: the published correspondence between Louis Althusser and Merab Mamardašvili (1966-1980), the discussion of Jacques Derrida with three Russian philosophers: Natalja Avtonomova, Valerij Podoroga, and Mikhail Ryklin (1990), and the joint project (20052008) on personal'nost' of Alexander Haardt and Nikolaj Plotnikov. In doing this, I apply the notions just outlined, but since we are not simply dealing with 'empirical' data, even if an empirical dimension is always involved and more important than we realize, the test does not even come close to an attempt to refute a hypothesis. Rather, we are in a field in which hermeneutics is the only feasible approach, and in which, by the end of the day, the proof of the pudding will be in the eating, i.e. if the conception here suggested helps us to make more sense of our experience. My focus will be on the often implicit perception of their philosophical culture by the participants.

\section{Troubled marxists in a torn-apart Europe}

In the period between Merab Mamardašvili's visit to Louis Althusser in 1966 and the latter's admission to a psychiatric hospital in 1980, the two philosophers maintained a private correspondence, the retrieved part of which was recently edited and published by Annie Epelboin, who often acted as a go-between, carrying letters across the border and telling Althusser about the situation in the USSR (Epelboin $2008,170)$. Notwithstanding the difference in age (12 years) and status as theoreticians, the two developed a close and warm friendship. It did not, however, lead to a profound dialogue or a noticeable influence (op.cit., 171). They shared, in those days at least, an interest in the works of Marx: Pour Marx (1965) and “Анализ сознания в работах Маркса (1968) [Analysis of Consciousness in the Works of Marx]" are rightly ranked as classics in Marxist philosophy (Mamardashvili 1986). But while Althusser was not only a deeply convinced Marxist who wanted "to understand what Marxism really means" (Althusser 1976,

\footnotetext{
5 I use "glocalization" in the sense given by Robert Robertson (1998); cf. also the definition by the wellknown writer and feminist Nawal el-Saadawi: "Globalization is imposed from above... Glocalization is the opposite movement. It is the power stemming from the oppressed world wide to change the situation to their benefit" (quoted from Bendadi (2008), 25; translation from the Dutch mine, EvdZ).
} 
141), but also a loyal member of the French communist party, Mamardašvili took a purely philosophical interest in Marx, was not a 'Marxist' (Mamardašvili 2004, 169 and 211), never mind a communist, and found much more philosophical substance in Husserl or Kant. It can be argued, by the way, that Althusser found greater philosophical substance in Spinoza, but was hampered by his dogmatic Marxism (Montag 1995, 65f).

If we approach the case of Althusser and Mamardašvili in terms of philosophical cultures and their interaction, we should emphasize, first of all, that each of them was 'marginal' in his own philosophical culture. Althusser certainly was a celebrity in left-wing intellectual circles in the 1970s and 1980s, but his position, though respected, became oppositional rather than mainstream after 1968, while Mamardašvili, in the same year, lost his illusions about the humanity of socialism and became a semi-dissident (Epelboin 2008, 169), a 'marginal' figure institutionally and, later on, a cult-figure and "role model for the intelligentsia" (Boobbyer 2005, 198; Swiderski 2006, 137-139). Still each of them was unmistakably part of their local philosophical culture: in the case of Althusser the French Marxist circles, which formed a sub-culture in France and Europe, and in the case of Mamardašvili Soviet philosophical culture, which turned him into its bestimmte Negation (Van der Zweerde 2006, 180-186).

For both thinkers, the events of 1968 were crucial, but in opposite ways. Althusser deplored the fact that the "quasi-revolution" in Paris in May lacked a Lenin, a person who could "foresee it and direct it" (Epelboin 2008, 177). For him, Marxism failed to assume the political role that its theory implied. By contrast Mamardašvili, who felt the oppression that took hold of Soviet life after the crack down in Prague in August, decidedly turned against any possible 'political' role of philosophy, Marxism included, thus taking the truly political step: "For us, the right politics is the depolitization of philosophy [Pour nous, la bonne politique, c'est la dépolitisation de la philosophie]..." (Epelboin 2008, 178f; Epelboin 2009, 357f). They wrote to each other in this period, and from this episode in their correspondence a clear difference between the socio-political conditions of philosophical culture appears: while Mamardašvili had no choice but to remain as quiet as possible within his niche at the Institut Rabočego Dviženija, Althusser had the free choice to stop his collaboration with the Soviet authorities and with the $\mathrm{PCF}$ - an act which, as Epelboin rightly emphasizes, would have been truly political, and a step which Mamardašvili suggested he should take (ibid.). Instead, he dramatically closed his eyes and mind (Epelboin 2008, 182-186; Epelboin 2009, 360-363).

The encounters with a significantly more 'free' philosophical culture that Mamardašvili had experienced in Prague in the early 1960s made him painfully aware of the specificities of Soviet philosophical culture, even if personally he managed to remain as cheerful as before. When Althusser finally visited the USSR in 1974 on the occasion of the Hegel-congress, Mamardašvili introduced him to his milieu, the philosophical circles that existed between dissent and officialdom. Althusser, however, refused to arrive at the obvious conclusion that the USSR was an oppressive system with little space for creative work in philosophy, Marxist philosophy included - a country in which, in fact, he would have been in serious 
trouble himself. His well known "Idéologie et appareils idéologiques d'État" of 1970 is intended as a critique of class societies, but was in fact eminently applicable to the USSR.

With the advantage of hindsight, it is possible to relate Althusser's incapacity to face the political realities of his day to his mental illness, and to consider him a 'case' "in the sense in which one speaks of a 'Wagner case' or a 'Nietzsche case'", 6 Epelboin finds it too easy, however, to oppose Mamardašvili and Althusser as 'le Sage et le Fou', because what drew them together was not only their pedagogical talent, but also their concern for each other and their profound friendship (Epelboin 2008, 190). Yet in the Russian version of the text, she does include a reference to Althusser's "mental illness," while in the French version she merely mentions "a fundamental disequilibrium." In line with this, Althusser's "capacité à tenir des propos éloignés de toute réalité" is rephrased, for the Russian readership, as "the capacity to express completely meaningless judgements [способностью высказывать совершенно бессмысленные суждения]" (Epelboin 2008, 171; Epelboin 2009, 350). Epelboin's invaluable publication, which is the material presence, in both philosophical cultures, of the history of this philosophical friendship across the Iron Curtain, thus manifests the very 'double speak' that marked their exchange.

We can thus see this correspondence as a reflection of the difference between two philosophical cultures: an oppressive one that turned philosophy into a political instrument, a culture which Mamardašvili refused to recognize, a refusal for which he paid a high price but by virtue of which he retained his dignity, on the one hand; and on the other hand one which combined freedom of public expression with the utter ineffectiveness of philosophical theory for want of a Lenin-a culture whose advantages Althusser refused to countenance. They thus both ended up as prominent inhabitants within the philosophical counter-cultures of their respective countries. It is clear why, in contrast to the dominant Soviet culture and due to his 'marginalized' place in it. Mamardašvili is celebrated today as one of the few 'real thinkers' of the Soviet era. If not by virtue of the content of his thinking, then at least by its form, his free-style "consciousness aloud [сознание вслух]," he saved genuine philosophical thinking (Mamardašvili 2004, 87). Althusser, on the contrary, is mostly remembered as the tragic figure who strangled his wife and of whose 'dogmatic' Marxism little remains today. Both suffered, one feels tempted to say: one because he was on the right side of the wrong situation, the other because he remained on the wrong side of the right situation. Such judgments, however, suffer from what one could call the 'disadvantage of hindsight', and thus not only fall short of doing justice to the theoretical merit of their writings, but also, and more importantly, fail to see the real opposition between two thinkers one of whom wrote, in 1989, that "thought exists only in its very occurrence, only in a space that is not occupied by prejudices, prohibitions, etc." (Mamardašvili 2004, 42), ${ }^{7}$ while the other stated, in 1975, that

\footnotetext{
6 '...qui fait d'Althusser un "cas", au sens où l'on parle d'un "cas Wagner" ou d'un "cas Nietzsche”...' (Rosset 1992, quoted from Epelboin 2008, 189.

7 'Мысль существует только в исполнении, только в пространстве, незанятом никакими предрассудками, запретами и т.д.'
} 
“une philosophie... n'existe que par la position qu'elle occupe, et n'occupe cette position qu'en la conquérant sur le plein d'un monde déjà occupé" (Althusser 1976, 141). The difference between a metaphysics of free thought in unoccupied space and a metaphysics of struggle between positions in a single replete space obtains its full significance only against the background of the distinct philosophical cultures within which these positions were expressed.

\section{Back to the USSR!! Derrida and Moscow postmodernists}

In February 1990, the year in which both Mamardašvili (in November) and Althusser (in October) died, Jacques Derrida was in Moscow for a two-week visit. This trip clearly made an enormous impression on him: the long report on this trip, which he presented a month later in California, clearly shows Derrida's awareness-sometimes bordering on hyper-awareness - of the historical parallels, the determining conditions, the selective character, and the singular significance of his voyage. Contrary to Althusser 15 years earlier, Derrida appears to have been all eyes and ears, without naïveté or wishful thinking, and fully aware of the historical significance of perestrojka, not only for the then still existing USSR, but also for "Bucarest, Prague, Budapest, Berlin" (Derrida 1995, 37). During his visit, he met with three well-known Russian philosophers, Natalja Avtonomova, Valerij Podoroga, and Mikhail Ryklin, at the Laboratory for Post-Classical Philosophical Investigations of the Institute of Philosophy for a conversation on philosophy and literature.

The conversation itself was bilingual: Derrida spoke English, the three Russian philosophers spoke Russian, and Elena Petrovskaja provided the translation. The text of this conversation first appeared in Russian in 1993, edited by the Russian participants (Ryklin 1993, 151-186). A German translation of this Russian edition was published in 1995 (Ackermann et al. 1995, 173-199), and a French version appeared in the same year, translated from the English and authorized by Derrida (Derrida 1995, 103-155). In the interview, Derrida says: "Il y a traduction et la traduction est impossible" (Derrida 1995, 120), and the German editors use this statement as a motto for their publication as a whole: "Übersetzung ist unmöglichaber es gibt die Übersetzung" (Ackermann et al. 1995, 11). Ironically, the original of which these two statements are the translation is itself a translation, since the 'original original' was Derrida's spoken English. As Ryklin puts it: "Im vorliegenden Fall fungiert die Übersetzung selbst als Original" (Ackermann et al. 1995, 260). ${ }^{8}$ However, the French and the German version do not state the same thing: the first reads "There is translation and the translation is impossible," which in English sounds awkward unless one stresses "the," suggesting "the single translation" or "the (only) real translation"; the German version reads "Translation is impossible, but there is the translation," which also sounds awkward and which, if taken literally, contradicts the French version: the translation is impossible, but there is the translation. This would make sense, for example, if one stresses and modifies: "The translation is impossible, yet there is this translation," i.e. the one the reader is

\footnotetext{
$\overline{{ }^{8} \text { Quoted from Ryklin (1993), } 7 .}$
} 
holding in her or his hands. This does make sense, since they were speaking about the plurality of translations of a poem by Clément Marot. ${ }^{9}$

The text of the original English recording was: "There is translation. Translation is impossible...." ${ }^{10}$ This text leaves open the connection between the two phrases, thus allowing both "and," "but", and "yet." Moreover, the phrase does not contain any articles, contrary to the German and French versions just quoted: it contains the 'zero article'. The Russian version is unambiguous with respect to the connection, but ambiguous with respect to the articles: "Вот перевод-но перевод невозможен" (Avtonomova et al. 1993, 162). In Russian, this is a grammatically correct sentence, but it leaves, contrary to the English zero article, the article undecided: it can be both "the" or "a"; with emphatic "но" the Russian makes a clear choice for an opposition: "but". This fits the German translation, with its "aber," but it contradicts the French "et" in the version that was authorized by Derrida (Avtonomova et al. 1995a, b). However-and here we really get to the bottom of the difficulty-Derrida was speaking English, not his native tongue, however well he spoke it. An 'idealist' might ask whether he was saying in English what he was thinking in French, a 'structuralist' would argue that that is an impossible question by definition, whereas a 'realist' like Derrida himself would claim that it is impossible to reach behind the actual utterance, yet there is a differrance between thought and utterance that serves to explain why, in what we say, there inescapably are the traces of imperfection of our own expression, implying, among other things, that "I don't know how to say what I think" is not a nonsensical statement. Derrida authorized the French version, but he did this several years after the event... so this was what he then thought he had meant when he said it in English a few years earlier. Even though we do know what was said initially, we are still with the same problem of translation from English into Russian, and then French and German: which of the four variants expresses 'what Derrida was thinking'? The possibility exits, of course, that this was a post-modernist tongue in cheek game, meant precisely to show, rather than 'say', the issue at stake, but even then, the question remains, since obviously the participants were thinking and expressing what they thought.

What does this mean for the understanding of philosophical culture? The important thing to note here is that we are not dealing with a philosophical concept that is bound to a particular philosophical tradition, such as sobornost' or Aufhebung or dispositif, but, on the contrary, with an everyday concept that can be unequivocally translated: translation, Übersetzung, traduction, перевод. We are, however, dealing with an important philosophical category, namely determinacy. Here, the corresponding notions in Russian and German, определённость and Bestimmtheit, cannot be unequivocally rendered in English or French: determinacy and determinedness, détermination and déterminicité do not cover the meaning. More importantly, however, the absence of articles in Russian (and other Slavonic languages), contrasting with their presence in Latin and Germanic ones, determines

\footnotetext{
9 Avtonomova tells, during the conversation, that Douglas Hofstadter had taken a poem by Marot and sent it to his friends all over the world, including herself, asking them to translate it and send it back, if possible even in several versions (Derrida 1995, 199f; Ackermann et al. 1995, 181).

${ }^{10}$ My gratitude goes to Dirk Uffelmann for providing the original text.
} 
the range of possible renderings. Therefore, what holds for a translation of poetry, equally holds for philosophy: the exactly intended meaning cannot be rendered, and there is no place for synthesis or compromise-only for explanatory notes. Hence there is a specific philosophical content that is bound up with the determinationslinguistic ones, in this case - of the philosophical culture at hand. The encounter between different philosophical cultures makes clear, to the participants, that there is no one-to-one correspondence between singular terms in different languages (and, within languages, idioms, vocabularies, etc.). There is no extra-linguistic 'point' from where to tackle such problems, yet everything in the encounter points in its direction.

Irrespective of whether somebody prefers the abstraction of German, the indeterminacy of Russian, the elastic rationality of French, or the common sense character of English, irreducible differences are at work here. Such perceptions and preferences stem from a position that transcends the 'philosophical culture of departure' yet remains bound to it in the sense, at least, that thought must be expressed in some language. There is no such thing as 'language in general', except in the speculation of philosophers like Vladimir Solov'ëv. ${ }^{11}$ These speculations are far from idealistic: transcending the determinations of any language is 'real' in every attempt at translation or at understanding across languages. It is this translingual and transcultural transcendence which opens a realm of philosophy beyond linguistic determination: it is connected to what Épstein labels "the right to live beyond one's culture, on the borders of cultures" (Berry et al. 1999, 82). One of the emerging questions is whether such a movement of transcending the particularity of one's own philosophical culture takes one to a new 'place', e.g. a universal culture, a culturally neutral universal humanity, as Solov'ëv suggested, or whether it is the movement of transcending that counts, a "transcendence into nothing" as Mamardašvili called it, with the accompanying awareness that the "borders of cultures" will be a place of endless discussion which by definition transcends them (Mamardašvili 2004, 197).

At this point, we encounter two possible, opposed patterns of reaction. One consists of a 'jump' towards an allegedly universal discursive space, i.e. global philosophical culture, populated by philosophical cosmopolitans who communicate and argue in a philosophical newspeak which, in fact, is a reduced form of English, stripped of idiomatic expressions and enriched with technical jargon that, in principle at least, can derive from any other language. Roughly speaking, this is the language in which this paper is written. The alternative is a retreat into the specificity of one's own philosophical culture, intimately connected with a native language, determined by the specificities of a local history (in the present-day world usually a national one), and backed by an essentialist understanding of culture-

\footnotetext{
11 "True unity does not annul multiplicity but finds its realisation in it, setting it free from the limitations of exclusiveness. One language inspired by the Spirit of God means communicability and understanding between many distinct languages, which are divided but do not divide. (...) The true unity of languages is found not in a single language but in an all-embracing language, that is, in an interpretation of all languages which would make them equally understandable to all while the peculiarity of each would be preserved" (Solov'ëv 1988, 500f; cf. English translation: Solov'ëv 2005, 365f).
} 
defensive parochialism and tolerant multiculturalism obviously share the same culturism.

About two of Derrida's three interlocutors, Podoroga and Ryklin, Ulrich Schmid wrote:

In einem sehr grundsätzlichen Sinne ist sogar das postmoderne Denken, das in den neunziger Jahren in Russland Hochkunjunktor hatte, der Sowjetvergangenheit verhaftet geblieben: Das Auseinandertreten von Zeichen und Bezeichnetem, das seinen archetypischen Ausdruck in der sinnlosen Nichtentsprechung von ritueller Propaganda und sowjetischer Alltagstristesse fand, ist auch die semantische Grundlage der philosophischen Dekonstruktion, wie sie etwa von Boris Groys, Mikhail Ryklin, Valerij Podoroga oder Mikhail Ėpstein betrieben wird. Die Dekonstruktion stößt mithin in Russland auf ganz andere Voraussetzungen als in Westeuropa... (Schmid 2003, 21) [italics mine, EvdZ]

We might infer from this that the conditions of doing philosophy, in this case post-modern(ist) philosophy, are strongly different in Russia from those in Europe, due to irreversible historical differences, in this case the replacement, already in the 1930s, of signs with a 'signified' by 'mere signs' without reference-another word for 'vacuous ideology replacing reality' - and that this provides a typical example of the general cultural and, in this case, also political conditions of philosophical culture. While this is not per se untrue, it should be added that Schmid's hidden presupposition that in other situations, notably that of Western Europe, deconstruction is not confronted with such a "separation of signifier and signified" and that European "ritual propaganda" and "Alltagstristesse" are totally different (or even absent), is what really determines the interaction between the two philosophical cultures. Both need to identify, and they do so by being each other's constitutive other.

It is part of the way in which these philosophical cultures, as distinct and opposed, yet communicating, come into being, i.e. are discursively constructed, in the first place, and it is part of the way in which the very title of Schmid's book, Russische Religionsphilosophen des 20. Jahrhunderts, begins to make any sense. If we want to find an answer to the obvious question "Why is there such a thing as 'Russian philosophy' in the first place?," if we want to avoid an essentialist understanding in terms of a 'Russian soul', and if we yet want to maintain that the notion 'Russian philosophy' means more than just the language in which philosophical writings are stated, then we need to look at such 'micro-constructions' as titles, and the presuppositions and decisions that they entail.

In the reflected perception of both post-Soviet Russian philosophical culture and the European academic culture from which Schmid practices his study of Russian philosophy, there is a conviction that there was something specifically Soviet and particularly wrong with Soviet socio-political reality, something which continues to determine post-Soviet philosophical culture in Russia, just as there is a shared assumption, between Schmid, his publisher, and their audience, that there is something specifically Russian and particularly interesting about 20th century Russian religious philosophy, something which continues to shape and justify the 
attention European philosophical culture pays to its Eastern neighbour. The point is not in the truth or untruth of these convictions and assumptions, but in the way in which they operate in the reproduction of a plurality of philosophical cultures, reflecting each other.

\section{Intimate asymmetry}

In May 2005, the year in which Derrida's Moscou aller-retour appeared in print, a conference was held at RGGU in Moscow, financed by the German Volkswagenstiftung and jointly organized by Alexander Haardt and Nikolaj Plotnikov, two philosophers who with their close cooperation materialize the revived close cooperation between Russian and German thinkers. A few years later, the proceedings of his conference appeared, in Russian (2007) and German (2008), and the two editors wrote an introduction which appeared in both editions. Although the two versions of the introduction are mostly identical, there are significant differences between them that are instructive for the topic of this paper, i.e. the relation and interaction between European - in this case: German ${ }^{12}$ — and Russian philosophical cultures.

A first difference concerns philosophical vocabulary. The Russian edition begins by stating the "self-evident conviction in contemporary philosophical discourse" that the notion of person [личность] is "a key concept for the philosophical consciousness of the West," whereas the German edition makes the same claim concerning the centrality of person [Person], but omits "the West," stating instead that it belongs to the "key notions, which articulate and reflect the basic assumptions of human cognition and action". ${ }^{13}$ The message is clear, yet different for both audiences: within the context of German philosophical culture the book is about philosophy of cognition and action tout court, whereas Russians implicitly are offered the lazejka - to employ the Bakhtinian notion-to argue that what follows is about Western, and thus not necessarily about their own 'philosophical consciousness'. The German introduction further elaborates, without any reference to geography or language, thus situating the text at the level of 'just philosophy', the conceptual field around 'Person' and suggests delineating a semantic field that unites, in the way of Wittgensteinian family resemblances, various discourses of 'Personalität' - the latter being, in German, a slightly academic notion, but one that makes sense immediately. At this point, the Russian version has to make a move: although ličnost' is a common Russian word, that can be rendered alternatively as person or personality, it is already an abstract notion. Consequently, when the editors speak about the same semantic field they have to introduce a new notion, this

\footnotetext{
12 The "non-Russian" presence in conference and publications was largely German, but also included a Polish-American-Swiss philosopher, Edward Swiderski, and a Dutch one-the author of this paper.

13 Haardt et al. (2008), 11: "In der philosophischen Diskussion der Gegenwart besteht ein weit verbreiteter Konsens darüber, dass der Begriff der Person zu den Schlüsselbegriffen gehört, die die Basisannahmen des menschlichen Erkennens und Handelns artikulieren und reflektieren"; Cf. Plotnikov et al. 2007, 7: "Ubeždenie v tom, čto ponjatie ličnosti (v smysle lica - Person) javljaetsja ključevym dlja filosofskogo soznanija Zapada, imeet $\mathrm{v}$ sovremennom filosofskom diskurse kharakter pročnoj očevidnosti."
} 
time entirely artificial, in order to point to “... a certain general field of meanings, which can be designated with the artificial (for the Russian language) term of personal' nost"'. ${ }^{14}$ We thus witness here an attempt to enrich Russian philosophical vocabulary: if this attempt is successful, it is in this very instance that the difference between two philosophical cultures is actually overcome. More generally, it will have to be in instances like this-given the fact that in Russia today philosophical concepts are no longer introduced 'from above' as they were before (this remark suggests indeed that one of the specific differences of Soviet philosophical culture was the top-down introduction of vocabulary). If, in an unforeseeable future, personal' nost' will have entered the standard vocabulary employed in philosophical discourse in Russia, a difference will have been overcome, that now still exists in the form of terminological hegemony: it is from German to Russian that this notion is transferred, not the other way around. At the micro-level, therefore, we witness an example of a process that has a history of at least two centuries: the adoption, within Russian philosophical culture, of European, in particular German vocabulary (due to grammatical similarities the translation of German philosophical language into Russian is much easier than into French or English).

A second significant difference concerns asymmetry. Every philosophical culture contains perceptions of all other philosophical cultures it has access to: this comes to the fore in specialized fields of comparative studies (Arabic, Chinese, Indian philosophy, etc.), in networks of people who are into this or that 'other' philosophy (non-Western, African, native American, etc.), in conferences and summer schools, in occasional elective university courses, etc. More generally, this asymmetry appears in the images and perceptions of all other philosophical cultures within a given philosophical culture, bearing in mind that these images and perceptions can also be, as it were, 'zero', i.e. 'absence'. For German philosophers-those who have not specialized in the study of Russian philosophy, that is-it will generally come as a (pleasant) surprise that Russia has a much stronger, more interesting, and more lively philosophical culture than they would have expected. Anybody who is familiar with the field knows the attempts, by specialists in Russian philosophy, to raise interest in their area of study among their colleagues, and also knows that these attempts are often in vain: to the extent to which it is different it is too exotic, to the extent to which it is familiar there is no particular need to pay attention. This points to an important asymmetry that, I suggest, has more to do with the general pattern of relations between philosophical cultures than with the specific characteristics of the two cultures in question. In other words: the general lack of interest and knowledge with respect to Russian philosophy among West European philosophers has to do, irrespective of the actual import of Russian philosophy, with the self-reproduction of West Eurepean philosophical culture, which, like, any philosophical culture, has to neutralize disturbing information from its 'surrounding' (not per se in the spatial sense). Philosophical cultures differ from each other in how they relate to other philosophical cultures, as well as to their 'inner' differentiation, but I venture the hypothesis that certain patterns can be detected.

\footnotetext{
14 Plotnikov et al. 2007, 7: “... некое общее поле значений, которое можно обозначить искуственным (для русского языка) термином персональность."
} 
During the Soviet period, a clear distinction was established, in philosophy curricula and in the organizational structure of philosophy departments, between two fields of history of philosophy: istorija otečestvennoj filosofii and istorija zarubežnoj filosofii. This distinction is still in place at Russian universities, and it always strikes visitors from 'the West'. It would be interesting to see if similar distinctions are present in other major non-Western philosophical cultures: Chinese, Arabic, Japanese, Indian, Turkish, etc. ${ }^{15}$ My hypothesis is that these cultures, in a similar vein, broadly distinguish 'native' and 'foreign', whereas Western philosophical culture will distinguish between a number of 'world philosophies', - Chinese philosophy, Indian philosophy, Islamic philosophy, Russian philosophy — on the one hand and philosophy tout court, i.e. Western and global philosophy, on the other. This difference points to an important asymmetry in perception that has to do with cultural hegemony. There is a striking parallel here between philosophy departments and music stores: in Russia the latter have sections for 'fatherland music' and 'foreign music' respectively, whereas a Western music store will usually have a section for 'world music' - an expression in which 'world' actually means 'the rest of the world' - and a larger section for music without further qualification. The shop owner who puts Manu Chau, Youssou N'Dour or Kolibri under 'just music' instead of 'world music' makes a relevant decision in the micro-politics of culture. The point is not if 'the West' is 'the best' or 'better' than 'the rest', but that discourse is construed in such a way that 'the West' and 'the rest' come into existence, yielding, to quote Samuel Huntington, a "world... divided between a Western one and a non-Western many."16

This asymmetry comes to the fore in a key sentence in the introduction by Plotnikov and Haardt. After pointing out, with reference to the notion of "indicator" in the Begriffsgeschichte introduced by Reinhart Koselleck, that "the concepts which constitute the semantic field of personality... are key concepts for modern European consciousness" (Haardt et al. 2008, 16; Plotnikov et al. 2007, 11), the authors emphasize a "peculiarity of the discursive self-determination [Selbstbestimmung/самоопределение] of Russian thought," namely "a conscious takingdistance [Distanzierung/дистанцирование] from the language of European philosophy," which in the German rendering takes place "not infrequently [nicht selten]" and in the Russian version "permanently [постоянно]" (ibid.). The asymmetry appears instantly if one imagines the opposite situation, viz., German thought consciously taking a distance from the language of Russian philosophy. Examples are a rejection of the Leninist principle of partijnost' [Parteilichkeit, usually rendered in English as partisanship, but actually better translated as partymindedness ${ }^{17}$ of philosophy and other cultural and intellectual phenomena, or a hesitation to identify too quickly the Slavophile notion of sobornost' with the concept of Gemeinschaft as found in Tönnies. However, such issues are marginal in

\footnotetext{
${ }^{15}$ For example, Zeynep Direk of Gatalasaray University, Istanbul, is engaging in an attempt to write, for the first time in history, a non-biased history of Turkish philosophy that does not end with either the beginning or the end of the Ottoman Empire.

16 Huntington (1998), 36; cf. the map of "The West and the Rest" on p. 22-23 in the same book.

17 Cf. Ballestrem (1964).
} 
German or European philosophical culture. The point, therefore, is not that there is a difference in vocabulary, but that there is a contrast in the ways of dealing with it: conscious and frequent distancing on the one hand, marginal hesitations on the other.

A third difference comes to a fore, finally, when the editors point to a form of Russian exceptionalism. They first indicate a similarity between German and Russian philosophical culture in that in both cases "these concepts ["Person," "Persönlichkeit," "Ich," "Subjekt," EvdZ] are attributed a 'key function'." Then a difference is pointed out when they state that because "they [the concepts just mentioned, EvdZ] display (much like the concepts "Democracy,", "Property," and "State") a tendency towards 'politicization' and 'ideologization', this history equally forms an important part of all-European Begriffsgeschichte" (Haardt et al. 2008, 16; Plotnikov et al. 2007, 11). Not only is a difference stated between Russian and German philosophical culture, the latter apparently lacking 'politicization' or 'ideologization', which implicitly invokes the opposition between abused or instrumentalized versus pure or genuine philosophy, but also this difference is stated differently. It is reasonably supposed that Russian readers understand the notions of ideologization and politicization without quotation marks, and they are likewise assumed to understand the expression "European philosophical ideologemes," an assumption that fails with respect to the German audience, which is largely ignorant of the very word "ideologeme." In the German text we read: "Da in der russischen Kultur-und Ideengeschichte diesen Begriffen ebenfalls eine ,Schlüsselfunktion' zugewiesen wird, und sie eine Tendenz zur ,Politisierung' und ,Ideologisierung' aufweisen (ähnlich Begriffen wie ,Demokratie', ,Eigentum', ,Staat'), stellt auch diese Geschichte einen wichtigen Part in der gesamteuropäischen Begriffsgeschichte dar". In the Russian text: "Poskol'ku i v russkoj intellektual'noj istorii èti ponjatija vozvodjatsja $\mathrm{v}$ rang ključevikh, pričem s kharakternoj dlja evropejskikh filosofskikh "ideologem" tendenciej k politizacii i ideologizacii (napodobie ponjatij "demokratija", "sobstvennost"” ili "gosudarstvo"), postol'ku i ona predstaet kak čast' obščeevropejskoj istorii ponjatij” [italics mine, EvdZ].

All this is certainly not meant as 'criticism' of the editors, Haardt and Plotnikov, for adapting to the two different philosophical cultures they were dealing with. Quite the contrary: they did a wonderful job. The point is, however, that they could not not do a 'job' at this point-there is a job to be done. The way they did this job reflects some of the peculiarities of the two philosophical cultures in their mutual interaction: a certain hegemony in terms of philosophical vocabulary, an asymmetry in the relation between the two cultures, and the assumed 'ideologization' in the Russian case and the lack thereof in the German case. The authors, together inhabiting as it were the shared discursive space of both philosophical cultures, while at the same time creating and expanding it, not only are aware of the difference but concreticize it in their very choice of words and expressions-they thus realize it in the two senses of that verb. It is, of course, also possible to be naïve in this respect, but that would be to miss the specificity of philosophical culture that is constitutive for both mutual understanding and misunderstanding. The authors in question are certainly not naïve in this respect. 


\section{Conclusion}

The model of philosophical culture that emerges from the examples discussed in this paper is of course bound to the case under examination, i.e. the interaction between West European (French and German) and Russian philosophical culture, and it remains to be seen whether and how the same model suits other cases. Also, the interaction here addressed must be seen against the background of, on the one hand, twentieth century European history, ${ }^{18}$ with the Soviet system and the post-World War II division of the continent as major determining factors, and, on the other hand, a much longer period of interaction and influence (largely one way) that was broken off by the events of 1917 and 1922. ${ }^{19}$ Russian and West European philosophical cultures have long known about each other, the Silver Age in Russia being a period of flourishing and increased interaction between them. The attempt to start again from the period of interaction during the first two decades of the twentieth century, is one of the parameters of Russian philosophical culture today. In this sense, we are dealing with a rather specific situation. Nevertheless, we can state a few general conclusions.

First of all, we can assess the interaction between representatives of two different philosophical cultures with the help of the concept of "horizon of understanding." [Husserl]. Any philosophical culture (or other communicative space) functions by virtue of a shared horizon of understanding and perception that is not habitually articulated, but presupposed. The encounter with another philosophical culture can be called successful to the extent to which participants succeed in expanding their horizon, an attempt that can, ultimately, lead to a fusion of horizons. The friendship between Althusser and Mamardašvili shows a remarkable contrast between the utter failure of the former to open up the horizon of his dogmatic Marxism, both philosophically and politically, and the principled openness of the latter, who lost his illusions concerning 'socialism' in 1968. In their case, what worked in the kitchen did not work in philosophy. If we read Derrida's account of his trip to the USSR, "Back from Moscow, in the USSR," which he presented in California after his return (and which inevitably involves both the Beatles and the Beach Boys) (Derrida 1995, 26f), we witness a courageous attempt to expand his horizon under simultaneous recognition of the impossibility of such an attempt. In a typically Derridaean paradox, the expansion of the horizons of the participants consists in the shared recognition, yet irreducibly different perception of this impossibility. In the case of Plotnikov and Haardt, finally, there already is the shared horizon of their joint attempt to organize a Russian-German philosophical Begriffsgeschichte, which, in the very recognition of the differences at stake, transcends them. Their project is a projection of a new, common horizon, and when they present the outcome of their endeavour to the two audiences they both place the two philosophical cultures within the broader horizon of their comparative approach and

\footnotetext{
18 Cf. Epelboin (2008), 171: "Elles [the letters Mamardašvili and Althusser wrote to each other, EvdZ] dessinent les contours d'une incomprehension qui, à mon sens, ne concerne pas seulement deux individus mais l'histoire du $\mathrm{xx}^{\mathrm{e}}$ siècle.".

19 For a more detailed account, see Khoruzij (1995), Chamberlain (2006), and Van der Zweerde (2008).
} 
make present the irredeemable differences between the two, not only in terms of their 'characteristic features', but also in the terms of their mutual perception. Ideally, we witness here two matching processes of horizon expansion, which can lead to a shared discursive space: shared vocabulary, shared acknowledgement of the perceived asymmetry between the two cultures, shared perception of possible 'ideologization' and 'politicization' of philosophy. Still, even if the field demarcated by their respective horizons were identical, the horizons would be different because different parts of each would be the 'expanded' ones. Therefore, a full fusion of the horizons of given philosophical cultures can only emerge, I venture, in the case of, say, a student of Haardt and Plotnikov who is 'raised philosophically' in this sharedbut-not-common horizon. However, this would be a third horizon from the standpoint of each of the previous perspectives. All this may sound far-fetched or abstract, but it is, I suggest, what really happens at any conference on Russian philosophy in a Western country, and I see no reason why it would be any different in other cases. (It can partly be compared to a situation in which scholars, raised in different philosophical paradigms, try to understand each other, but I suggest that such a situation still has a shared background.)

Secondly, the endeavour presented here figures among philosophical comparative studies, it is part of what is usually called meta-philosophy. The task ahead, one level up, would be that of 'comparative comparative studies', i.e. a comparison of the ways in which philosophical cultures compare themselves with each other. My general hypothesis for such an endeavour is that one is likely to find strong resemblances and structural analogies in all such comparisons. I would expect there to be an increasingly similar pattern in each philosophical culture. This is precisely the meaning of 'glocalization' in this context, including the fact that each philosophical culture, under conditions of mondialisation in the Derridaean sense, relates to (potentially all) other philosophical cultures by developing a field of comparative studies, thus reflecting, like a Leibnizian monad, all the others in itself. The very possibility of writing this last sentence, however, implies that philosophical cultures are not Leibnizian monads, but transcend themselves in the way suggested by Mamardašvili. From this angle and under conditions of mondialisation, any attempt to develop or protect a local philosophical culture, such as an 'authentic Russian philosophical discourse', is 'reactionary' in the literal sense of that term, while any move to identify with global philosophical culture, however nobly cosmopolitan its motivation, is to participate in a hegemonic structure that, itself, must be transcended. The obvious critical question as to how a 'neutral' or 'objective' position is possible from which such statements can be made in the first place is answered by the very question: to be able to pose this question presupposes the non-coincidence of the place from which the question is posed with the space comprising the range of possible answers.

Finally, all three cases here chosen are examples of concreteness. A partly preserved and largely private correspondence between a half-dissident Georgian bon-vivant and a intermittently depressed French dogmatic Marxist is perhaps important in their respective biographies, but their friendship went unnoticed outside small circles and it did not have major effects at the level of theory. On the contrary: Epelboin shows that it did not affect Althusser's thinking the way it might 
have, had his mind been as open as his heart. Besides, who today takes an interest in the discussions among Marxist philosophers in the period before 1991? A visit by a French-Algerian philosopher to the Institut filosofii in Moscow was perhaps a ripple on the surface of Russian history and a minor event in the history of philosophy as a whole, however important it may have been for the participants. At the same time, it is a crucial event in the interaction between two philosophical cultures, as is materially testified by the publication of the proceedings in several languages. This publication came about as the result of decisions to publish the materials, of existing networks, expected audiences etc. There surely is a degree of contingency at play here, as is the case in any 'publication history', but the crucial point, when it comes to philosophical culture, is of course which publications succeed or fail, have effect or drop dead, etc. By the end of the day, such 'contingent' events are what history concretely consists of. Finally, a conference organized by a German and a Russian philosopher on the topic of Personalität/Персональность is one of many joint conferences on a variety of topics in a field, philosophy, that is academically marginal anyway, while at the same time it is a concrete event in the revived exchange between German and Russian philosophy, hosted by two key figures in that exchange. This is not to inflate the importance of this particular event, but rather to claim that this kind of event is what exchange between philosophical cultures consists of.

What we can conclude at this point is that the historical development of the interaction between philosophical cultures consists, at least partly, of such 'minor' events. It is in those encounters and exchanges that philosophical cultures appear in their specificity: in mutual perceptions, expectations, and evaluations. Any model of philosophical culture, and arguably any model of culture in general, must take this into account-culture, philosophical or other, exists only as lived culture, not as abstract model. At this point at least the 'freethinking prisoner' Mamardašvili rather than the 'self-confined' Althusser was right, and Derrida was right to argue that, although translation is impossible the very failure is itself successful exchange: "La résistance à la traduction est la traduction" (Derrida 1995, 121).

Open Access This article is distributed under the terms of the Creative Commons Attribution Noncommercial License which permits any noncommercial use, distribution, and reproduction in any medium, provided the original author(s) and source are credited.

\section{References}

Ackermann, A., Raiser, H., \& Uffelmann D. (Eds.) (1995). Orte des Denkens; neue russische Philosophie. Wien: Passagen Verlag.

Althusser, L. (1976). Soutenance d'Amiens. In idem, Positions (pp. 139-185). Paris: Éditions Sociales. Avtonomova, N. et al. (1993). Filosofija i literatura; beseda s Žakom Derrida. In Ryklin, 151-186.

Avtonomova, N. et al. (1995a). Philosophie et littérature; entretien avec Jacques Derrida. In Derrida, pp. $103-155$.

Avtonomova, N. et al. (1995b). Philosophie und Literatur; ein Gespräch mit Jacques Derrida. In Ackermann et al., pp. 173-199.

Ballestrem, K. G. (1964). Russian philosophical terminology (in Russian, English, German, and French). Dordrecht: Reidel.

Bauman, Z. (1988). Globalization: The human consequences. Cambridge: Polity Press. 
Bendadi, S. (2008). Dolle Amina's. Amsterdam \& Antwerpen: Meulenhoff/Manteau.

Berry, E. E., Epstein M. N. [Ëpstein] (1999). Transcultural experiments; Russian and American models of creative communication. New York: Palgrave McMillan.

Boobbyer, P. (2005). Conscience, dissent and reform in Soviet Russia. London \& New York: Routledge.

Botz-Bornstein, T., \& Hengelbrock, J. (Eds.). (2006). Re-ethnicizing the minds? Cultural revival in contemporary thought. Amsterdam \& New York: Rodopi.

Cassin, B., et al. (Eds.). (2004). Vocabulaire européen des philosophies; dictionnaire des intraduisibles. Paris: Seuil.

Chamberlain, L. (2006). The philosophy steamer; Lenin and the exile of the intelligentsia. London: Atlantic Books.

Derrida, J. (1995). Moscou aller-retour; suivi d'un entretien avec. In Avtonomova, N., Podoroga, V., Ryklin M. (Eds.), Paris: Éditions de l'Aube.

Derrida, J. (2001). L'Université sans condition. Paris: Galilée.

Epelboin, A., "Destins croisés de deux philosophes: la correspondence Louis Althusser-Merab Mamardachvili”, Lignes 20 (mai 2008), 169-190 [in Russian: Анни Эпельбуэн (2009), “Переписка М.К. Мамардашвили с Луи Альтюссером". Москва, 2009].

Haardt, A., \& Plotnikov, N. (Eds.) (2008). Diskurse der Personalität; die Begriffsgeschichte der 'Person' aus deutscher und russischer Perspektive. München, Wilhelm Fink [in Russian: Николай С. Плотников, Александр Хаардт [ред.] (2007), Персональность; язык философии в руссконемецком диалоге, Москва].

Huntington, S. P. (1998). The clash of civilizations. London: Pocket Books.

Khoruzij, S. S. (1995). Posle pereryva; puti russkoj filosofii. St. Petersburg: Aleteija.

Lefort, C. (1983). "La question de la démocratie". In P. Lacoue-Labarthe \& J.-L. Nancy (Eds.), Le retrait du politique. Paris: Galilée.

Mamardašvili, M. K. (1986). "Analysis of Consciousness in the Works of Karl Marx", Studies in Soviet Thought 32, 101-120 [original in Boпросы философии 1968, 6, 14-25].

Mamardašvili, M. K. (2004). Soznanie i civilizacija [Raboty XIX]. Moskva: Progress-Tradicija.

Montag, W. (1995). «The soul is the prison of the body»: Althusser and Foucault, 1970-1985. In J. Lezra (Ed.), Depositions [Yale French Studies 88] (pp. 53-77). Yale: Yale University Press.

Robertson, R. (1998). Glokalisierung: Homogenität und Heterogenität in Raum und Zeit. In Beck, U. (Eds.), Perspektiven der Weltgesellschaft. Frankfurt am Main: Suhrkamp. (pp. 192-220).

Rosset, C. (1992). En ce temps-là; notes sur L. Althusser. Paris: Les Éditions de Minuit.

Ryklin, M. (1993). Žak Derrida v Moskve. Dekonstrukcija putě̌estvija. Moscow: Ad Marginem.

Schinkel, W. (2007). Denken in een tijd van sociale hypochondrie. Kampen: Klement.

Schmid, U. (2003). Russische Religionsphilosophen des 20. Jahrhunderts. Freiburg \&c: Herder.

Solov'ëv, V. S. (1988). Opravdanie dobra. In Sočinenija v dvukh tomakh. Moscow: Mysl' [in English: Vladimir S. Solov'ëv (2005), The Justification of the Good. Grand Rapids MI: William Eerdmans].

Swiderski, E. M. (2006). Editor's preface. Studies in East European Thought, 58, 137-139.

Vadén, T. (2006). "What is "Local Thinking"? (Can There be Finnish Philosophy?)". In Botz-Bornstein 2006, 219-236.

Van der Zweerde, E. (2006). Philosophy in the act: The socio-political relevance of Mamardašvili's philosophizing. Studies in East European Thought, 58, 180-186.

Van der Zweerde, E. (2008). La place de la philosophie russe dans l'histoire de la philosophie mondiale. Diogène, 223, 115-137. 